\title{
Rahvatantsuharrastus paguluseestlaste hulgas ja selle roll eestluse säilimisel ${ }^{1}$
}

\author{
Iivi Zajedova, Eha Rüütel, \\ Angela Arraste, Kalev Järvela
}

\begin{abstract}
Teesid: Käesolev artikkel toetub Saksamaal pagulaseestlaste hulgas läbi viidud uurimusele, mille eesmärgiks oli intervjuude kaudu saada pagulaseestlaste kogemuslik tagasivaade eesti rahvatantsurühmade tekkimisele ja arengule ning seda mõjutanud teguritele Saksamaa Liitvabariigis pärast Teist maailmasõda. Intervjuud viidi läbi 13 rahvatantsuga tegelenud väliseestlasega Bocholtis ja Hamburgis. Rahvatantsu rolli iseloomustavate kategooriatena tulid esile rahvatantsu järgmised funktsioonid: järjepidevuse jätkamine; kogukonna organiseerimine; sotsiaalne suhtlus ja heaolu; eesti keele säilitamine; enesemääratlemine. Rahvatants ei olnud ainult harrastustegevus, vaid aitas inimestel ennast muudatuste keerises määratleda, oli eesti keele kõnelemise ja oppimise kohaks, aitas poliitiliselt raskel ajal kokku hoida, ning oma tantsude ja rahvarõivaste kaudu kohalikule rahvale Eestit lähemalt tutvustada.
\end{abstract}

Märksõnad: identiteet, kultuurimälu, kvalitatiivne uurimus, pagulaseestlased, rahvatants, Saksamaa

Eestlastel väljaspool Eestit on märkimisväärne osa meie ajaloos ja kultuuris ning eestluse edendamisel maailmas. Välis-Eesti kogukonnad on loonud seltse, koole ja klubisid, mille aktiivsus on kestnud paguluse algaastatest tänini. Viimastel aastatel ongi väljaspool Eestit asuvate kaasmaalaste seas alustatud uuringuid, mida toetab ka Eesti Vabariigi valitsuse Rahvuskaaslaste programm 2009-2013. Teema tähtsust tõestavad nii valitsuse korraldatud rahvuskaaslaste konverentsid (12. ja 13. novembril 2007, 6. ja 7. augustil 2008) kui ka kultuuriministeeriumi ja Tartu Ülikooli ühisprojekt "Diasporaa roll Eesti iseseisvuse taastamisel" (Kristi Anniste, Kaja Kumer-Haukanõmm, Tiit Tammaru 2008). Tartu Ülikooli Välis-Eesti uuringute keskus (VEUK) on avaldanud mitmeid analüüsivaid materjale nagu Suur põgenemine 1944. Eestlaste lahkumine läände ja selle mõjud (Kumer-Haukanõmm \& Rosenberg \& Tammaru 2006). Ajakirjas Mäetagused on ilmunud artikleid, mis kajastavad akadeemilisi uurimusi folkloorist, kommetest ja diasporaast (Kõiva 2001, Korb 2005, 2001). Pagulasaastate algust Saksamaal kirjeldab F. Kooli 1999. aastal ilmunud DP Kroo- 
nika: Eesti pagulased Saksamaal 1944-1951 (Kool 1999). ${ }^{2}$ Ilmunud on ka eestlaste identiteeti käsitlevaid uurimusi (Bertricau 2001, Kõiva 2007, Valk 2002).

On uuritud kodu-eesti rahvatantsu positsioone (Vissel, 2004: 109-127) ning Eesti rahva pärimuskultuuri ja harrastustegevust (Eesti Kirjandusmuuseumi etnomusikoloogia osakond on avaldanud mitmeid suuremamahulisi töid, nt Rüütel 2004; Ojamaa \& Rüütel, 2002; Rüütel \& Tiit 2005, 2006). Eestis levis rahvatantsuharrastus 20. sajandi alguses kiiresti peamiselt koolide ning spordi- ja karskusseltside kaudu, saades tugeva impulsi veel 1934. aastal toimunud I Eesti mängudel. ${ }^{3}$ Rahvatantsu propageerija Anna Raudkatsi (Raudkats 1926, tsit Vissel 2004 järgi) arvates pidi tants olema meeldiv lõõgastus, mis aitab unustada igapäevased mured ja arendab tantsijais ühtekuuluvustunnet. Rahvatantsuharrastus pidi äratama ka armastuse rahvapärase kunsti vastu. Oli see ju tugevalt seotud vana kultuuripärandiga, loov ja sümboolne, viidates ühisele päritolule, omadustele ja saatusele, mis on rahvusliku identiteedi üheks oluliseks komponendiks. Identiteedi mõiste ise on lai ja seetõttu kasutatakse seda sõltuvalt kontekstist (vt Lenovský 2006: 14; Karu \& Valk 2005: 1975; Anniste \& Kumer-Haukanõmm \& Tammaru 2008: 137-155). Identiteeti on defineeritud järjepidevusena erinevate põlvkondade vahel: isad-emad, vanaisadvanaemad jne. Lähtudes Peter Weinreichi (1989: 50-73) ideest võib öelda, et identiteeti tuleks nähtavasti käsitleda ajalise järjepidevuse alusel kujunenud samasustundena.

Sotsiaalsetel rühmadel ja indiviididel on vaja talletada minevikku, sest see tähendab oma identiteedi äratundmist ja mõistmist. Samal ajal on see võimas vahend, mis aitab seada eesmärke tulevikuks. Inimest võib käsitleda pidevalt teel olijana, saatjaks teatud ambivalentsus, sest suundub ta ju tundmatut tundma õppima, säilitades samas seda, mis tuttav ja teada (Valsiner 2007b: 349). Ühise mineviku mälu ei ole kunagi neutraalne, see toetub valikutele, mis kindlustavad kogukonna positiivse identiteedi ja minevikumälestuste tark valik aitab ehitada rahulikku tulevikku (Bellelli \& Curci \& Leone 2007).

Uurija Kalev Katuse arvates on rahvuslik identiteet väga ühemõtteline eestlus on midagi, mis on ainuomane vaid Eestile. Ja see miski eristab meid teistest rahvustest (Katus 1997: 71-93). Aastakümneid on eestlaste silmis olnud au sees rahvuslik vorm - rahvariided, rahvalaulud, rahvatantsud ja rahvapeod. Niisugune eneseväljendus on muutunud spetsiifiliseks enesemääratlemise ja -kehtestamise vahendiks mitmel eestlastele poliitiliselt kriitilisel ajal.

Eestlaste harrastustegevust sõjajärgsetes pagulaskeskustes võib käsitleda kui olulist enesesäilitamise alustala. ${ }^{4}$ Vaatamata esialgsele turvatunde puudumisele (või just sellepärast) sai valdavaks ühtne rahvustunne ja enesemääratlemine. Kuna Eesti rahvusluse kontseptsioon on tugevalt konservatiivne ja minevikkuvaatav, leidis rahvuslik kultuuriline tegevus eestlaste hulgas tuge- 
va kõlapinna (Vissel 2004: 111). ${ }^{5}$ Kultuuripsühholoogia käsitleb kultuuri osana inimese psühholoogilisest süsteemist, st kultuur kuulub individuaalsesse psühholoogilisse süsteemi ja mängib seal teatud funktsionaalset rolli (Valsiner 2007a: 27).

Nii olid rahvalaulud ja -tantsud ning rahvarõivad Eesti põgenikele pärast Teist maailmasõda nagu juured kodumaas, mis toetasid toimetulekut uues keskkonnas. Näiteks vaatleb Kõiva (2007) oma artiklis kuidas austraaliaeestlased muutuvates oludes konstrueerisid oma füüsilise ja kognitiivse avaliku ja privaatse ruumi ning väljendasid selle kaudu identiteeti. Sealjuures etnilist identiteeti väljendavad sümbolid ja kujunduselemendid ühis- ja privaatruumides sarnanesid kodumaal kasutatutele.

Kohalikud kogukonnad on kajastanud harrastustegevusi nii väliseestlaste ajalehtedes kui ka ajakirjades (Eesti Rada, Eesti Elu, Eesti Hääl, Rahvuslik Kontakt jne), samuti on paiguti kirjutatud rahvatantsuharrastuse lokaalsest ajaloost, kuid puuduvad uurimused, mis selgitaksid pagulaseestlaste rahvatantsuharrastuse rolli laiemalt.

\section{Kogumismatk Saksamaal ja selle tagapõhi}

Pole raske arvata, miks valis uurimisrühm esimeseks andmete kogumise kohaks just Saksamaa:

Suure 1944. aasta sügispõgenemise lõppedes oli Saksamaale jõudnud kümneid tuhandeid eestlasi. Nende koguarvuks arvati isegi 65 000, aga tõenäolisem number on ligi 40 000. Kolmanda Riigi kokkuvarisemise eel asusid nad laiali üle maa, Berliinist Austriani välja (Erelt 2004).

Eestist põgenenud ei saabunud Saksamaale sugugi ühtse rahvusrühmana. Vastavalt Hamburgis asunud eestlaste koloonia ühe juhi, Tartu ülikooli professori Julius Mägiste liigitusele jagunesid nad neljaks rühmaks: 1939. aastal siirdusid Saksamaale eelkõige baltisakslased ja kadakad, 1941. aastal nn järelümberasujad (enamasti tööjõulised noored), aastail 1942-1944 töölaagritesse sattunud töökad eestlased ja 1944. aasta septembris-oktoobris saabunu sõjapõgenikud (Erelt 2004). Paljudel Teise maailmasõja lõpus Eestist põgenenutel kujunes seetõttu esimeseks asupaigaks mõni laager liitlastsoonides Saksamaal. Saksamaale jäänud eestlastelt võis saada laiemat teavet edasisest eestlaste teekonnast sobiva töö- ja elukoha otsingutel nii Saksamaal kui ka mujal maailmas - Belgias, Suurbritannias, Austraalias, Rootsis, Kanadas, Ameerika Ühendriikides. 
Saksamaal põgenikelaagrite kitsastes oludes, ${ }^{6}$ kus eestlased elasid aastaid, käis elav seltsi- ja hariduselu: asutati omakeelsed koolid, kogudused, kirjastused, moodustati laulukoorid, tantsurühmad, võimlemisrühmad, teatrid, ja klubid ning 1947. aastal korraldati Saksamaal Augsburgis isegi laulupidu (Kool 1999: 779). Seetõttu polegi ime, et põgenikelaagrites tekkisid ka tantsurühmad. Pagulusse põgenenud olid enamasti tööeas kodanikud, olles eelnevalt seotud rahvusriigi rajamisega Eestis. Suurt ja erilist osa harrastustegevuses hakkas mängima Eestist omariikluse algaastatest kaasa toodud kultuuripilt.

Käesolev uurimus on leidnud heasoovlikku vastukaja pagulaseestlaskonnas (avatud suhtlemine, ligipääsu võimalus arhiividele). ${ }^{7}$ Kahjuks aga avaldab mõju aeg, sest uuritav protsess algas enam kui kuuskümmend aastat tagasi ja paljud, kes olid nende sündmustega seotud, on meie hulgast juba lahkunud või auväärses vanuses. ${ }^{8}$ Pealegi on suuremalt jaolt tegemist koduste materjalikogudega, millede pikaajaline säilimine pole garanteeritud.

Uurimuses otsisime vastust küsimustele, mis põhjustas Saksamaa pagulaslaagrites nii aktiivset harrastustegevust, sealhulgas ka rahvatantsurühmade teket.

\section{Uurimuse metoodika}

Rakendatud on kvalitatiivset meetodit, mis võimaldas uurida intervjueeritavate seletusi seoses rahvatantsuharrastusega. Eesmärk oli kaardistada rahvatantsu rühmade teket ning uurida rahvatantsu osa eestluse hoidmisel ja säilimisel pagulaseestlaste hulgas. Eriliseks huviobjektiks olid Teise maailmasõja järgsed aastad Saksamaal, pagulaseestlaste ja nende järglaste tegevus sel ajal.

Andmete kogumisel kasutati struktureerimata intervjuud ja vestlust, mille peateemad olid seltsielu (sh rahvatantsurühmade tekkimine); liikmeskond, liikmete omavahelised suhted ja eesmärgid; seltsielu ja rahvatantsuga seotud tegurid (repertuaar, muusika, esinemised, rahvarõivad, tegevuse finantseerimine); rahvatantsuharrastuse tähendus pagulaseestlaste hulgas.

Peateemade alusel püüdis uurimisrühm leida oma intervjuudega kinnitust arvamusele, et

- rahvatantsuharrastus aitas liita välis-Eesti kogukonda ja säilitada eestlust;

- rahvatantsijad aitasid säilitada rahvarõiva kandmise traditsiooni;

- rahvatantsuharrastus aitas poliitiliselt raskel ajal organiseerida ühisaktsioone, tutvustamaks kaude Eesti okupeerimist. 
Vestlused ja intervjuud viidi läbi 13 Saksamaa Liitvabariigis elava eestlasega. 2006. aasta novembris viidi läbi vestlus kolme inimesega Bocholtis: HK (80aastane naine), RK (83-aastane mees), RZ (HK poeg, 57-aastane mees). Vestlus toimus HK ja RK kodus. Bonnis Annabergi külalistemajas (lätlaste ja eestlaste traditsiooniline ürituste korraldamise koht) toimus üks individuaalintervjuu, LP (85-aastane), ning rühmavestlus seitsme inimesega: AK (80-aastane mees), JK (81-aastane mees), MKV (57-aastane naine), KR (48-aastane naine), RL (50aastane), LKL (46-aastane), SR (57-aastane mees).

Kaks intervjuud toimus 2007. aasta juunis Hamburgis: VJ (61-aastane naine) ja GB (63-aastane naine) VJ kodus.

Kõik 2006. ja 2007. aastal Saksamaal toimunud vestlused ja intervjuud videosalvestati ning transkribeeriti (säilitati teksti algkuju ja keelekasutus). Planeeritud intervjuude kava ei õnnestunud alati rakendada, seetõttu ei ole tekstide analüüsil aluseks võetud esialgset teemade loetelu, vaid alustati vabast kodeerimisest. Seejärel moodustati rahvatantsuharrastust ning rahvatantsu funktsioone iseloomustavad kategooriad. Artiklis toodud intervjuutekstid on lühendatud ja keeleliselt veidi korrigeeritud, kuid on püütud säilitada intervjueeritavate esitusstiili. Videosalvestused ja transkribeeritud intervjuutekstid ja muud uurimuse materjalid säilitatakse TLÜ Kunstide Instituudi rakendusloome osakonnas.

\section{Tulemused ja analüüs}

\section{Rahvatantsuharrastusega seotud kategooriad}

Intervjuude analüüsil tulid esile:

I Tantsukohad: a) põgenikelaagrid, b) suvised laste- ja noortelaagrid c) rahvapeod, d) esinemised.

II Ajendid: a) varasem tantsukogemus, b) põgenikelaagrites koos elamine, d) meelelahutus, e) soov oma lastele rahvatantsu õpetada.

III Tantsurühmade tegutsemine: a) entusiastid ja päris tantsuõpetajad, b) treeningud/harjutustunnid, c) repertuaar - legendaarne Ullo Toomi tantsuraamat, d) muusika, e) rahvarõivad, f) toetused, g) poliitilise tooniga demonstratsioonid.

IV Rahvatantsurühmade tegevuse hääbumine ja rahvatantsu huvi praegu.

Kategooriaid läbis seos rahvatantsu ja eesti keele vahel. 


\section{Kus tantsiti?}

Rahvatantsurühmi nimetati intervjuudes peamiselt linnade järgi: Stuttgardi rühm, Hamburgi rühm, Kölnis oli linnaosa järgi rühma nimeks Worts Estov. Ainukeseks rahvatantsurühmaks, mis tegutses pikemat aega (1973-1991) ja mida mäletasid enamik intervjueerituid osutus Bocholtis tegutsenud Põhjala, mille juht oli Helgi Kivi.

a) Palju tantsiti põgenike laagrites.

JK (81-aastane mees): Laagrites, igal pool, kus eestlasi oli [---] lauldi ja tantsiti.

GB (63-aastane naine): Neid oli ju massiliselt, [---] kes elasid laagrites. [---] Mõned olid Hamburgi eeslinnas, mõned olid natuke eemal. [---] Nad kutsusid meid ja kui oli kas jõulupidu või vabariigi aastapäev, suvepidu, siis ikka läksime laulsime ja tantsisime. [---] Oldenburgis olid ju ka suured laagrid ja seal nad elasid koos ja tantsisid, laulsid koos.

LP (85-aastane naine): Meil oli üks noormees, kes no kaks korda kuus kindlasti [tegi] põgenikkudele kokkutulekuid. Sääl siis tantsisime ja laulsime ja küpsetasime kodukooki ja igaüks pidi midagi tegema. Osta midagi ei saanud, meil raha ei olnud, söök oli prii.

b) Lastele ja noortele olid tantsude õppimise kohaks suvised laste- ja noortelaagrid (suvelaagrid, suvekodud, skaudilaagrid), mida korraldati väliseestlaste lastele igal suvel. Laagrid kestsid kolm nädalat ja küsitletute mälestuste järgi tuli sinna kokku 30-50 last.

KR (48-aastane naine): Mina olin lapsena suvelaagrites ja seal olid laulukoorid ja rahvatantsugrupid. Seal ma tantsisin, kuna seal linnas, kus mina üles kasvasin, ei olnud ühtegi eestlast.

Suvekodudes ja skaudilaagrites tundus peaeesmärk olevat siiski eesti keele ja ajaloo õppimine, see toimus hommikupoolikuti, pärastlõunaid sisustasid tantsimine, laulmine ja muud huvitegevused. Suheldi eesti keeles ja kohati peeti sellest nõudest väga rangelt kinni.

GB (63-aastane naine): Range kord oli [---] see oli tõesti nii range kord suvekodudes. Poisid pidid isegi vist nurka seisma, kui nad rääkisid saksa keelt. [---] Ma ei tohtind ju magamissaalis ööbida suvekodus. Ütlesid, et kui on üks "must lammas", siis kõik räägivad saksa keelt. Ma pidin teise tallu minema ja seal ööbima. Ja siis ütlesid, jah, kui sa nü̈̈d talvel ilusti 
õpid eesti keelt, siis tuleval suvel sa võid ka magamissaali tulla. Kas oli stiimul? Oli ikka.

c) Igal aastal korraldati mitmeid rahvapidusid nii oma eesti kogukonnale kui ka laiemale publikule. Peod võimaldasid tutvustada eesti kultuuri, tantse ja laule sakslastele, näidata rongkäikudes ennast ja oma rahvariideid. Ja mitte ainult sakslastele, ka eestlased ise nautisid vaimustusega oma rahvarõivaste ja rahvakunsti ilu nagu selgub järgnevast lapseeast pärit meenutuses.

KR (48-aastane naine): Münster oli keskpunkt siin Saksamaal, Eesti Keskkomiteel oli peapunkt Münsteris. Ja seal [oli] suur suvepidu, ma mäletan. Igalt poolt tulid eestlased kokku. Rahvatantsu rühm oli väga-väga suur ja seda oli tore vaadata. Göteborgist, Stockholmist, igasugustest linnadest tulid kokku ja tantsisid. Ja ka koor oli.

Pidudel haarati tantsima kaasa ka vaatajaid.

HK (80-aastane naine): Düsseldorfis käisime kunagi tantsimas [---] neil oli mingisugune suur pidu väljas. [Ütleb kaaslasele:] Mäletad, sa ise tantsisid ka seal kaasa ja pärast võtsite need inimesed seal tantsima "Õige ja vasemat” - nii lihtsad tantsud, et pealtvaatajatest veel sai juurde võetud.

Rahvapidudel oli võimalus luua kontakte ja suhelda eesti keeles.

KR (48-aastane naine): Stockholmist ja Göteborgist tulid ju meeskoorid meile külla, kutsusime neid, kui need suured rahvapeod olid. [---] Ma käisin koolis, ma olin neliteist-viisteist. See oli siis 1964-65, sellel ajal. Peale selle oli igal aastal Münsteris või Helsingøris või Heidelbergis. Seal ma õppisin ka eesti keele ära.

d) Rahvatantsurühmade esinemised toimusid põhiliselt eestlaste pidupäevadel (jaanipäev, võidupüha) ja kokkutulekutel, aga intervjuudes mainiti ühiseid üritusi ka eestlaste-lätlaste, eestlaste-baltisakslaste ja sakslaste rahvatantsurühmaga, Ida-Euroopa kultuuripäevi ja põgenike kultuuripäevi, linnarahvale esinemas käimisi, ülesastumisi vanadekodudes ja saksa kollektiivide kutsel.

VJ (61-aastane naine): Nad tulid Göteborgist, nad tulid Lõuna-Saksamaalt, siis tantsisime kõik koos, mõnikord olime 20 paari, 30 paari.

Esinemisi oli ka välismaal (Hollandis, Belgias, Rootsis, Inglismaal) sealsete eestlaste kutsel. Ülemaailmsetel eesti päevadel esinemist piiras teinekord raha, teinekord ka pealehakkamine. 


\section{Mis ajendas tantsima?}

a) Varasem tantsukogemus. Osa vanema generatsiooni esindajatest oli õppinud rahvatantse juba Eestis koolis käies.

LP (85-aastane naine): Rahvatantsu tantsisin juba algkoolis [Eestis].

JK (81-aastane mees): Mina puutusin selle asjaga tõesti päris noorest peast kokku. Ma lõpetasin algkooli Viru-Jaagupis ja viimased klassid käisin Viru-Jaagupis 11-st 14-nda eluaastani, seal õpetati tookord ka rahvatantsu.

b) Rahvatantsurühmade teket soodustas põgenikelaagrites koos elamine, kus tants ja laul olid mõnus kooskäimise ja ajaveetmise vorm.

RL (50-aastane mees): Meeldis lihtsalt eestlastega seal koos käia. See oli, ma arvan, peapõhjus, ja kõik olid toredad inimesed, tahtsid inimestega kokku saada. Ma arvan, tants polnudki see [---] hirmsasti tantsuhimu polnudki, see oli rohkem inimeste himu. Seltskondlik elu oli ka väga tore seal [---] matkamised ja koosviibimised olid, käidi ka koos kodudes loomulikult.

VJ (61-aastane naine): Siin oli üks laager Hamburgis, seal saime kokku. Seal oli üks suur ruum meie jaoks, et saime seal tantsida ja laulda. Meid oli saja ümber [---] aga mitte rohkem. See oli nii, et meil oli siin üks proua. Ja tema siis õpetas eesti keelt ja [---] ma ei tea, kuidas me tantsu juurde tulime.

c) Meelelahutus. Tantsiti ja esineti lõbu pärast.

GB (63-aastane naine): Tjahh, lõbu pärast, pakkus lõbu ja see oli suur au ja me esinesime hea meelega ja eesti vaimuga [---] mingit raha ei ole küsinud. Isegi maksime juurde. [---] Mulle istub laulmine rohkem kui tantsimine. Kui oli vaja, siis ma tantsisin. Oskasime ju nagunii juba. [---] Kas tulid nü̈d Kölnist, Münchenist või Oldenburgist, ükskõik, kust nad tulid, see oli nagu üks suur pere. Laulsime, tantsisime koos.

d) Soov oma lastele eesti rahvatantsu õpetada võis viia tantsurühma moodustamiseni, mis hiljem aastaid tegutses.

HK (80-aastane naine): see [soov] tuli minu poolt, et see [rahvatantsurühm] kunagi oli. Lapsed kasvavad [---], et natuke eesti rahvatantsu ka neile õpetada. 


\section{Kuidas tantsurühmad tegutsesid?}

a) Tantsurühma tegevus sõltus eeskätt entusiastidest, kes olid valmis rühma juhtima. Oskused polnudki nii olulised, kui ettevõtlikkus. Kui tantsuõpetajat ei olnud, õpiti tantse Ullo Toomi raamatust (Toomi 1953). Näiteks võib tuua tantsurühma kujunemistee Bocholtis.

HK (80-aastane naine): Ma ei tea, mitu aastat ta [Liivaku nimeline tantsujuht] tegi ja siis lõpetas ära. Paar aastat ei olnud midagi. Siis ma mõtlesin, et tahaks ikka tantsugruppi teha. Aga ma ei osanud nii hästi seda õpetada, ma ei olnud ju [---] tegelenud ja siis ma lasin omal täditütrel saata rahvatantsu raamatu. No jah, siis me hakkasime peale [1973. a]. Meie rühm oli Põhjala, selle panin mina siis grupi nimeks. [---] Ja siis ma hakkasin seda [rahvatantsuraamatut] studeerima. Muidugi, algul lugesin nii kui hiina keelt, ei saanud aru [---] oma tuurid ja kõik. Siis ma pidin ju välja töötama selle tantsu [---] seal [proovis] ei hakka ju aega

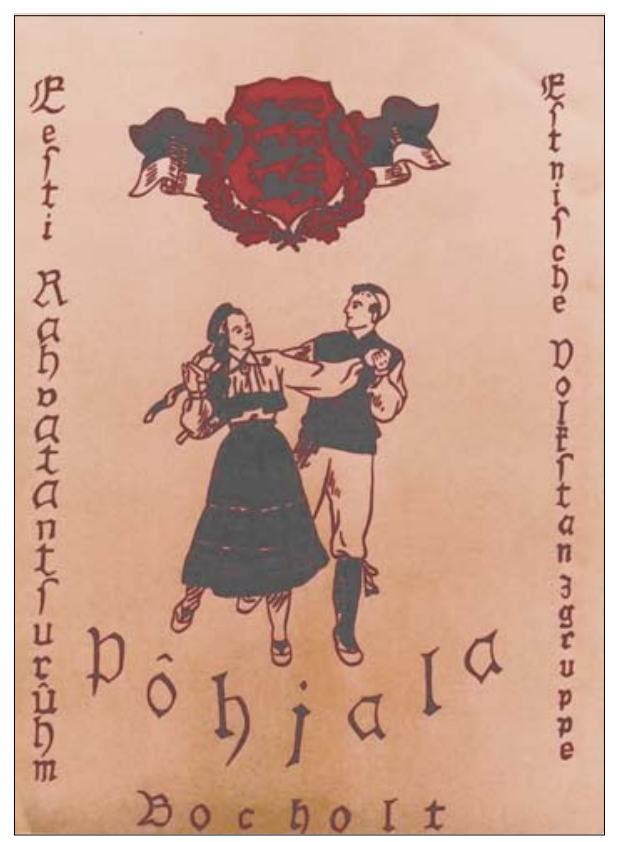

Tantsurühma Põhjala esimese peokutse esikaas viitma. [---] Ma tantsisin üksipäi-

ni, kogu aeg proovisin neid tuurisid. [---] Meil oli väike rühm, kuus paari. Tegin seda 16 aastat. Üheksakümne esimesel aastal lõpetasime, oli viimane esinemine.

Tantsurühma kujunemisteest Hamburgis rääkis VJ (61-aastane naine):

Mul on üks tädi [---]. Tema õpetas eesti tantsu, aga need ei olnud õiged rahvatantsud. See oli nii natukene enda moodi tehtud. [---] Kui tema abiellus ja siit ära läks, siis mina võtsin selle üle. Need inimesed, kes olid Oldenburgis, nemad olid natuke vanemad kui meie ja nende käest ma õppisin ka tantse [---] kus nemad óppisid, seda ma ei tea. See oli 1965 või 1964, siis oskasime juba neid tantse. Ma ei õpetanud enam, ma olin nagu juht, et [---] proove teha. Kõik oskasid ja mina vaatasin, et nad korralikult tantsivad, et need vahed oleks korralikult. 
Mõnel rühmal läks ka nii, et Eestist asus Saksamaale elama päris tantsuópetaja. JK (81-aastane mees):

Kui täpselt siis meie neid [tantse] tundsime või oskasime õpetada, see oli iseasi. [---] Meie asi muutus pärast hoopis paremaks. Meil tuli sinna asundusse elama üks inimene, [---] tuli abielu läbi sinna, kes oli olnud Eestis päris rahvatantsu õpetaja.

b) Vanema põlvkonna inimesed rääkisid, et rahvatantsu treeningutel/harjutustundidel käidi ka pika maa tagant. Tuldi näiteks Hollandist, sest neil oli tantsurühma jaoks vähe eestlasi. Samas võis vahemaa hakata ka harrastust piirama.

LP (85-aastane naine): Proovid olid ainult kaks korda kuus. Just, et vahemaad nii pikad olid, ei saanud iga nädal [proovi] teha.

Treeningute kohta mainiti, et üldiselt toimusid need regulaarselt 1-2 korda nädalas 1,5-2 tundi. JK (81-aastane mees):

Seal [asunduses], kus me elasime, noh selline maja majas kinni, seal oli niisugune primitiivne ühiskonnaruum. Läksime sinna kokku nädala lõppudel ja harjutasime. [---] Pani meid rohkem tööle, et hing sees seisaks. Kas seda treeninguks nimetada, harjutamiseks võib.

Seevastu nooremate vastajate puhul tundusid treeningud olevat rohkem esinemistega seotud. GB (63-aastane naine):

Kui oli mingi üritus, siis pidime ju 2-3-4 korda ikka proovile tulema.

Suurte pidude puhul tuli hakkama saada suhteliselt väikese ettevalmistusajaga. JK (81-aastane mees):

[---] anti võimalus varem kokku tulla ühisprooviks. Sel päeval mindi siis varem kohale ja räägiti natukene asjade üle, prooviti mõnda asja. Samal päeval enne pidu.

Treeningutel käidi sageli perekonniti. LP (85-aastane naine):

[---] lühikest aega ma tantsisin Osnabrücki laagris. See ei olnud suur [rühm], võib-olla neli-viis paari. [---] Paar aastat alguses ma tantsisin oma mehega ja pärast ma tantsisin isegi oma pojaga, see oli Kölni rahvatantsugrupis.

Nähtavasti ei olnud rahvatantsuhuvilisi siiski eriti palju, sest vahel tuli "laenata" lisajõude teistest rühmadest. VJ (61-aastane naine): 
Poistest oli alati puudu [---] meil olid saksa poisid. Ja lätlastel puudusid tüdrukud ja meil oli poisse puudu. Nii et läti poisid tulid meile ja meie tantsisime läti grupis.

Eelnevat tantsuoskust rahvatantsurühmas osalemiseks ei nõutud. RL (50-aastane mees):

Ma olin võrdlemisi vilets tantsija. Mul on meeles, et isegi pisaratega pandi mind tantsima. Kõige hullem tants oli see, kus rütmis järsku vahetab midagi ja see ei jäänud mul meelde. Siis tehti alati trenn ekstra mulle. Selles [harjutustunnis] polnud palju jutuajamist, peale seda algas lõbus osa.

c) Repertuaar tundus varieeruvat sõltuvalt tantsujuhi oskustest ja teadmistest. Esialgu, põgenike laagris, tantsiti rahvatantse mälu järgi. Pärast Ullo Toomi (1953) raamatu Eesti rahvatantsud ilmumist, kasutati seda rahvatantsude õpetamisel nii Eestis kui ka väljaspool.

VJ (61-aastane naine): Meil on üks raamat [Ullo Toomi Eesti rahvatantsud], selle järgi õppisime.

GB (63-aastane naine): Meil oli see raamat ja repertuaari võtsime nii nagu meile öeldi. Õppisime ja saime selgeks. [---] Ah, keegi ikka teadis, kuidas käis.

RL (50-aastane mees): Need kerged [tantsud] olid jooksupolka, Naljapolka, Kalamees ja Tuljak. Ja siis, mida üldse tihti ei tantsita (Kriisi poisid tantsisid), see oli Kandali. Ma ei tea, kas see midagi ütleb, see suure pulgaga. Kandali, see oli vägev, see mulle meeldis, aga ma polnud mitte nii hea tantsija, need paremad tantsijad tantsisid ka Kandali. [---] See oli väga ilus. Siis Pulgatants loomulikult.

LP (85-aastane naine): kaerajaan, jooksupolka [---] need olid peamised rahvatantsud, mida peaaegu igaüks oskas. [---] Tuljak oli alati viimane tants. Seal olid ilusad sammud ja ka saksa publikule [meeldis].

HK (80-aastane naine): Meil oli 30 tantsu õpitud nende aastate jooksul, ja-ja, mul on meelest ära läinud need tantsud. Mul on [---] üks tantsuraamat [Ullo Toomi raamat] [---], mul on [seal] märgitud.

d) Rahvatantsu saatis põhiliselt akordionimuusika, kuid mõnikord tantsiti ka klaveri saatel (nt Hamburgis). Tuntud akordionimängija oli Edgar Pent, keda nimetasid kõik intervjueeritud. JK(81-aastane mees):

Iga eesti rahva pidu oli poolik, kui teda [Edgar Penti] pidul ei olnud. 
VJ (61-aastane naine): Meil oli üks pillimees. Tema oli tuntud üle terve Saksamaa - Edgar Pent. Tema siis mängis ja tema oli igal pool.

Mõnele poole siiski Edgar Pent ei jõudnud, kuid siis kasutati Edgar Pendi helisalvestatud muusikat, näiteks Stuttgardi rühmas. RL (50-aastane mees):

Kahjuks meil polnud pillimeest. Meil oli Edgar Pendi poolt sisse mängitud muusika. Kui esinemised olid, siis me proovisime ikka pillimeest saada, aga tihti see ei õnnestunud.

Appi tulid ka kohalikud saksa pillimehed.

HK (80-aastane naine): Saksa pillimees mängis akordioni, üks tore poiss oli, tema mängis kasseti peale [---] sellest raamatust [Ullo Toomi raamat], ta mängis kõik nootide järgi.

Uuringu käigus õnnestus rääkida ka ühe pillimehega, kes Edgar Pendiga koos mängis. AK (80-aastane mees):

No, sõber Edgar mängis akordioni ja siis mina natukene viiulit või trompetit. Tema kirjutas ka [---] noote. Enamasti olid meil need lood juba peas. [---] Oh, me mängisime Annabergis, Kölnis, Düsseldorfis, siis kui me eestlased koos olime, kas rahvuspühadel või siis ka üritustel [---] rahvatantsuks või muidu. Selle peale väljas ei olnud, et midagi teenida sellega, tundsime rõõmu sellest, et mängida saab ja ka teised rõõmustasid selle üle, et saab tantsu lü̈̈a.

e) Esinemistel kanti rahvarõivaid ja lugu peeti ehtsatest rahvarõivastest. GB (63-aastane naine):

mu tädi kudus ise [---] kõik oli ise tehtud ja kui ma olin kolmteist, sain tema käest kingiks. See oli minu jaoks suur kingitus. Siis ma sain kaasa teha, sest enne oli mul seelik ja pluusi, mis ei olnud ehtsad. [---] Ja mul oli alaväärsuskompleks, kuna kõik lapsed ütlesid: ah, see ei ole ju eht, kuidas sa siia tuled. See oli ju kohe näha.

Väikeste laste rahvarõivaid kombineeriti olemasolevatest materjalidest. LKL (46-aastane naine):

[---] kui ma väike laps olin, siis oli mu [esimene seelik] vanaema rahvariidest ülejäänud riidejupp ja mul oli niisugune väikese lapse seelik.

Päris rahvariiete saamine oli oluline sündmus. LKL (46-aastane naine): 
Ma sain [rahvariided], kui ma gümnaasiumi lõpetasin, kaheksakümne esimesel aastal. Ma ei tea üldse, kust mu vanemad siis need rahvariided hankisid. Need olid kusagilt Eestist [---] muhu rahvariided.

Tundub, et tüdrukute rahvariiete ehtsusele pöörati rohkem tähelepanu kui poiste rõivastusele. $\mathrm{RL}$ (50-aastane mees):

Tüdrukutel olid ikka õiged rahvarõivad, etnograafiliselt õige. Poistele oli võrdlemisi mugav variant valitud. Seal olid valged pluusid [---] emade poolt tehtud ja püksid olid nii tehtud, et ühe saksa rätsepa käest oli riie ostetud ja lasti lihtsalt ómmelda. See oli nii stiliseeritud, et paistis, nagu rahvarõivad oleksid õiged. [---] Pükstega see läks läbi, aga pastlad pidid siiski olema.

Kangas telliti, õmblus- ja tikkimistööd tehti ise. Kanga valmistamisel oli tuntud ja hinnatud Valda Koel Hannoverist, aga kangast telliti ka saksasoost kangakudujailt. VJ (61-aastane naine):

Me lasime kududa. Siin Hamburgis. Läksime raamatuga [Eesti rahvarõivad, 1957] sinna [---] ütlesime nendele täpselt, kuidas me tahame. Ja pluusid õmblesime ise. Tikkisime ise.

Võimalusel hangiti kangast ka Eestist. HK (80-aastane naine):

Läksime Tallinna [seitsmekümnendatel], mul on täditütre tütar tütrega. Ma rääkisin, et mul on ilmtingimata poistele tarvis riiet vestide jaoks. Tema ütles, et teab, kust riiet saab, [---] siis sain sealt osta poistele vestiriide.

Rahvarõivaste hankimisel ei olnud ükski vahemaa liiga pikk. KR (48-aastane naine):

Mul on setu rahvariided. [---] Minu tädi elas Austraalias. Nemad rändasid Austraaliasse peale sõda. Tema oli Võrus olnud õmblemismeister ja tema õmbles. Need on väga uhked ja vanasti ma kandsin neid ka jõulu ajal.

f) Esialgu põgenikelaagris olles ei saanud pagulased mingit toetust, loota sai ainult endale. Saksa riik hakkas alles hiljem, alates 1950. aastatest toetama vähemusrahvaste kultuuritegevust, kuid seda EÜSL (Eesti Ühiskond Saksa Liitvabariigis) keskorganisatsiooni kaudu, kes sai toetust taotleda ainult $50 \%$ ulatuses, ülejäänud pidi EÜSL kandma omafinantseeringuna. Toetust saadi ka Ameerikast ja Rootsist suvelaagritesse kutsumise näol. Saksamaalt pärit lapsed said seal kosuda mitu nädalat. Sellele järgnesid toetused ka ÜEKN 
(Ülemaailmse Eesti Kesknõukogu) poolt, kuid ka siin pidi taotluse esitama liikmesmaa esindus, milleks Saksamaal on EÜSL. Üheks toetuse allikaks oli ka Berliinis asuv EÜSLile kuuluv maja.

RZ (57-aastane mees): Meil oli, jaa, üks allikas ja see oli ja on ikka veel meie maja Berliinis.

Aktiivselt otsiti minimaalse tasu eest või siis hoopiski tasuta ruumide kasutamise võimalusi. Mõistagi olid need ruumid ka üsna tagasihoidlikud. Siinkohal nimetasid intervjueeritavad põhiliselt kas koolide võimlate kasutamist või siis näiteks rahvusvahelise organisatsiooni Christliche Ferein Junger Männer (Noorte Meeste Kristlik Ühing) poolt pakutud tasuta ruume jms.

Oli neid, kes leidsid, et rahaliselt toetati rahvatantsu piisavalt. RL (50-aastane mees):

Rahadega oli päris hea, [---] ma pidin ikka kas bussiga või rongiga sinna [tantsima] sõitma ja piletiraha sai makstud tantsurühma poolt. Ja ka neid rahvarõivad polnud vaja ise maksta, seal sai ka kuidagi kokku pandud. [---] Isegi väiksed honorarid olid arvatavasti, kui esinemised olid.

Nähtavasti ei olnud see nii aga igal pool, sest intervjuudes kõlas ka kriitilisemaid noote. JK (81-aastane mees):

Mis seal majandada! Oma kulud ja kirjad, kes meile seda maksis? Saksa riigilt me saime toetust [---] meie keskorganisatsioon sai sealt mingisuguse summa... Ja no see muidugi läks aastast aastasse kehvemaks. See, millest mina nü̈̈d praegu rääkisin, oli 1991-92. [---] Ma ei tea, millal see päris lõpp oli, iga aasta võeti ikka jälle oma 10\% maha ja [---] 1999 lõppes see.

Sellest hoolimata võib intervjuudest välja lugeda, et raha ei olnud rahvatantsuharrastuse puhul kõige määravam. LP (85-aastane naine):

Meie tegime ju vabatahtlikult kõik, me tegime seda rahvustundest. Me leidsime, et see on meie kohus teha, ilma et me ootaksime tasu.

Sageli ei pööranud tantsijad sellele ka tähelepanu, kui üritused olid huvitavad ning sõit, toitlustamine ja ööbimine olid korraldatud. LKL (46-aastane naine):

Lapsena ei jälgi, kust rahad tulevad või ei tule. Selle vastu ei tunne mingit huvi, aga ma arvan, me ei maksnud seal midagi omast taskust lisaks.

VJ (61-aastane naine): Ei, me ei saanud raha selle eest, et me tantsisime, aga meil oli ikka vaja sõita kuskile ja siis pidime sööma või magasime 
kuskil. Ja see oli organiseeritud. [---] Meile öeldi ainult, tulge sinna ja tantsige.

g) Suuri festivale meenutati kui poliitilise alatooniga demonstratsioone.

HK (80-aastane naine): [---] Lübeck, [---] Münster, [---] Geislingenis oli täitsa suur demonstratsioon.

RK (83-aastane mees): Kölnis on olnud, Heidelbergis. Seal oli väga suur demonstratsioon.

RZ (57-aastane mees): Bocholtis oli suur rongkäik. Terve Saksamaa oli kokku tulnud, linn oli kinni pandud.

Suured festivalid andsid võimaluse vaatajatele selgitada, kes on eestlased, kus on Eesti ja miks eestlased on Saksamaal. Enne esinemist tehti selgitustööd, siis tuli programm ja siis jälle selgitustöö. HK (80-aastane naine):

Tegime alati ju propagandat, kui meil siin mingi pidu oli. Siis sai alati ju ette loetud ikka, [---] meie ihaldatud riik [---] jajah, see oli meil alati propagandaks. Vat, et kus see Eesti üldse asub ja et ta on nüüd Vene all.

RZ (57-aastane mees): No siis tulid automaatselt inimesed juurde, küsisid, kus on Eesti.

LP (85-aastane naine): Laulukoor ja rahvatants [---] see oli meie relv. Sellega me tutvustasime [---] asukohamaades, kes me oleme, kust me tuleme, miks me siia tulime. [---] Ja meie ei tohtind Saksamaal poliitikat ajada, aga kultuurpoliitikat tohtisime ja sellega me tutvustasime ikkagi oma kultuuri, oma lauluvara, oma eesti keelt. Me kutsusime alati ministeeriumist ka saksa külalisi, aga me peokõned olid ikkagi kakskeelsedikka emakeeles ja pärast siis saksa keeles. Ja tead, mina ütlen, et see oli meie relv taasiseseisvumiseks, see oli meie panus. Ta annab mulle uhke tunde, vat eesti laulud on ilusad, eesti tantsud on ilusad.

\section{Rahvatantsurühmade tegevuse hääbumine ja rahvatantsu huvi praegu}

Tundub, et oli teatud sõjajärgne periood, mil rohkem tantsiti. Tantsurühmade tegevus lõppes tihti seetõttu, et noored abiellusid ning tantsupaare jäi rühma jaoks väheks ja järelkasvu ei olnud. Nii oli noorema põlvkonna puhul tavapärane, et alustati enamasti 8-10-aastaselt lasterühmas, siis mindi edasi noorte 
rühma ning pärast 20. eluaastat hakati seoses pere loomisega tantsutreeningutest loobuma.

HK (80-aastane naine): Minu lapsed kõik, kes mul seal [rühmas] olid [---] need abiellusid. Ühel oli 3 last, teisel oli 2 last. Siis oli ühel midagi ees, siis oli teisel [---] ja jäi mul lõpuks ainult 3 paari ja kolme paariga ma esinema ei saa minna. Kuus oleks pidanud alati olema.

Rahvatantsuga tegelemine oli laste puhul vastuvõetav, kuid tõsisemat tantsuga tegelemist ei pruukinud vanemad soosida. KR (48-aastane naine):

Mul oli väga range isa. Ta ei lubanud mul tantsukooli minna, kahjuks. Aga rahvatants, kui oli suured peod, suvepeod, aastapäevad, vabariigi aastapäevad, siis me esinesime, aga muidu, kahjuks mitte.

1990. aastad ja Eesti taasiseseisvumine tundus väliseesti rahvatantsult hoogu maha võtvat. Avanes ju siis võimalus käia Eestis laulu- ja tantsupidudel. RK (83-aastane mees):

Mina käisin selles [---] see esimene laulupidu, kui Eesti vabaks sai [1990]. [---] Minu vend oli Inglismaalt, õde oli Valgast, siis olime sääl [---] lauluväljakul. Ja tantsupeol käisime ka.

Tantsurühma saatus võis kujuneda ka selliseks nagu Stuttgardi rühmal, kus rühm lõpetas tegevuse seetõttu, et rühmajuht ja osa tantsijaid siirdus elama Eestisse. Nii hakati Stuttgardi rühmas tantsimise asemel laulma. Laulurühmaks üleminek näitas aga soovi jätkata ühiseid koostegemisi.

Päriselt ei ole aga huvi rahvatantsu vastu tänini vaibunud. LKL (46-aastane naine):

Kui siin näiteks keegi teeks ettepaneku, et me hakkame uuesti rahvatantsu tegema, mina oleksin kindlasti üks huvilistest, kes sinna tantsima läheks. [---] Jooksupolka võime [abikaasaga] kohe kaasa teha.

\section{Rahvatantsu roll pagulaseestlaste hulgas}

Lisaks rahvatantsu kirjeldavatele kategooriatele joonistusid intervjuudest välja rahvatantsu olulised funktsioonid pagulaaseestlaste hulgas.

Järjepidevuse säilitamise funktsioon. Enne Teist maailmasõda oli rahvatantsul eestlaste kultuuris kindel osa. Rahvatantsu õpetati koolides ning harrastati spordi- ja karskusseltside juures. Seetõttu olid paljudel pagulaseestlastel mitmed rahvatantsud teada (vt IIa). Tantsiti eestlaste koosviibimisel. 
Ükskõik, kust inimesed tulid, rahvatants ja -laul olid tegevused, mida osati, mis liitsid inimesi ja mis seetõttu olid traditsiooniliseks osaks eestlaste kogunemistel (vt IIc). Rahvatantsu olulisusele järjepidevuse kandjana viitab ka selle oskuse lastele edasiandmise tähtsustamine. Rahvatants kuulus laste suvelaagrite päevakavasse (vt Ib). Mõeldamatuna tundus, et lapsed kasvavad eesti rahvatantsuta (vt IIc, IId). Inimeste vastutustundele tantsuoskuse edasiandmisel viitab ka asjaolu, et tantse õpiti vanematelt inimestelt ning rahvatantsurühmi käivitasid professionaalsete õpetajate kõrval ka mitteprofessionaalid, õppides tantsusamme Ullo Toomi õpikust (vt IIIa, IIIc). Rahvatantsu juurde kuulusid rahvarõivad, mille ehtsust tähtsustati. Päris rahvarõivaste saamine oli lapsele või noorele suursündmus (vt IIIe). Võimalusel lasti kangas kududa ja õmblustööd teha Saksamaal, kuid rahvarõivaste hankimisel ei olnud ükski vahemaa liiga pikk, vajalikke kontakte oli selleks nii kodu-Eestis kui ka teistes eestlaste kogukondades, nt Austraalias (vt IIIe). Rahvatantsupeod ja demonstratsioonid andsid võimaluse tutvustada Eestimaad ja eestlasi ning sellega hoiti alal ja jagati teavet oma kodumaast ja kultuuriloost (vt IIIg). Tähtsaks peeti ka põlvkondade kokkusaamist ja kultuuri hoidmist.

LP (85-aastane naine): Eile mõtlesin, et mis ma terve päeva teen siin, aga nü̈̈ ma täna kuulsin, et oleks pidanud ikka tulema, eile õhtu oli nii palju tantsu olnud ja laulu, sellest ma jäin nü̈̈d ilma. [---] Minul on väga oluline noorte ringis ka olla. [---] Ajad on muutunud ja kõik jookseb teisiti, aga see põhi ikka jääb, miks me käime siin koos, need kultuuripäevad. On [vaja] eesti kultuuri ikka alal hoida, see on tähtis.

Kogukonda organiseeriv funktsioon. Rahvatants liitis eestlasi nende elukohtades, asukohamaades ning tõi tantsupidudele ja tähtpäevade tähistamisele kokku eestlasi erinevatest riikidest (vt I, IIIb), eelnevat tantsuoskust rahvatantsurühmas osalemiseks ei nõutud (vt IIIb). Harrastustegevuste kaudu räägiti kaasa kultuuripoliitikas ja tutvustati asukohamaades oma kogukonda ja traditsioone (vt IIIg). Rahvatantsurühmad toimisid vabatahtlikkuse alusel: [---] tegime hea meelega ja eesti vaimuga [---] mingit raha ei küsinud. Isegi maksime juurde .... (GB, 63-aastane naine, vt ka IIc).

1950. aastatest hakkas Saksa riik toetama vähemusrahvuste kultuuritegevust. Toetust eesti laste suvelaagritesse kutsumiseks hakati saama ka teistest riikidest (vt IIIf). Rahvatants oli ka perekondi liitev - sageli käidi treeningutel perekonniti (vt IIIb).

Sotsiaalse suhtluse ja heaolu funktsioon. Tants ja laul olid mõnusaks kooskäimise ja ajaveetmise vormiks (vt IIb, IIc). Harjutustunnis polnud palju jutuajamist [---] lõbus osa algas peale seda (RL, 50-aastane mees, vt ka IIIb). 
Rõõmu tunti kaunitest rahvariietest, tantsust ja laulust (vt IIIe). Harrastustegevused andsid jõudu, motiveerisid eestluse eest seisma, tõstsid enesehinnangut: $T a$ [eesti kultuur] annab mulle uhke tunde, vat eesti laulud on ilusad, eesti tantsud on ilusad (LP, 85-aastane naine, vt ka IIIg). Põlvkonna vahetudes suunas rahvatantsijate nappus avatusele ja tantsijate kaasamisele mitte-eestlaste hulgast (vt IIIb).

Eesti keele säilitamise funktsioon. Tantsutunnid toimusid eesti keeles. Inimestele, kes igapäevaselt eesti keeles ei suhelnud, andis see võimaluseks emakeelt rääkida. Eestlased kasutasid kõiki võimalusi, et lastele eesti keelt õpetada. Tantsutreeningud, rahvapeod ja laste suvelaagrid olid kohad, kus keelt omandati tegevustes (vt Ib, Ic, IIb). Eesti keelest oli juttu kõigis intervjuudes ning 2006. aasta Annabergi kokkusaamiselt jäi kõlama ka hiljem Saksamaale asunute soov olla koos ja ajada juttu teiste eestlastega, rääkida eesti keelt, nt KR (48-aastane naine):

üks põhjus oleks näiteks, et jälle oma vanade sõbrannadega kokku saada. [---] Ja ka oma emakeeles järjekordselt juttu ajada ja vahetada informatsiooni. [---] siin on kaks mängu ju, koroona ja jakkolo [---] ja teiseks ka, et me laulame õhtul.

Nähtavasti paneb ka vanus tantsuharrastusele oma piiri: rahvatants ei ole enam peamine põhjus, mille pärast praegu kokku saadakse, küll aga vesteldi sellest hea meelega.

Enesemääratlemise funktsioon. Eestist lahkujad olid eelkõige poliitilised põgenikud, kusjuures alguses oldi veendunud, et pagulus on ajutine. Seda kinnitasid ka mitmed intervjueeritavad.

LP (85-aastane naine): [---] ja selle lootusega me põgenesime, et tuleme tagasi.

HK (80-aastane naine): [---] et mis me välja [Ameerikasse] läheme, kui Eesti vabaks saab. [---] Ameerikast on ju suuri raskusi siis siia tagasi saada, [---] et mitukümmend aastat oli ju ikkagi see tahe, et nii kui Eesti vabaks saab [---] tagasi.

GB (63-aastane naine): [---] et tulge Saksamaale tööle, me pakume teile tööd ja siis nad läksidki. Tahtsid ainult veerand aastaks jääda, aga jäidki, kuni praeguseni. 
Kuid isegi siis, kui sai selgeks, et pagulus ei lõpe nii pea, jäi suhtumine endiseks - lastele õpetati eesti keelt ja anti edasi kõiki Eesti kultuuri puudutavaid teadmisi.

Harrastustegevus tekitas kodutunde, mille kaudu oli võimalik edastada ka eestlust rõhutavat kultuuripoliitikat. GB (63-aastane naine):

No et hoiame rohkem kokku, et meil on midagi, mis meid [---] ̈̈hendab. Jaa, mis meid ühendab. Andis ja annab kuni praeguseni. [---] Pool minu elust [---] see üks osa on minu pere ja teine osa on minu eestlus, kus ma kulutan palju aega, vaeva, energiat, närve. See on lihtsalt niimoodi.

VJ (61-aastane naine): See on mu terve lapseea ja noore naise elu olnud. See kuidagi oli mulle väga, väga tähtis. [---] Ma ei taha öelda, et me olime teistmoodi kui sakslased või nii, aga see oli mingisugune [---] nagu kodune tunne, me olime ikka koos ja see oli nagu suur pere. See oli meile ikka väga tähtis, et me olime eestlased.

Nii peeti ka rahvatantsu õpetust koolilastele ning noortele äärmiselt tähtsaks ja vajalikuks identiteedi alahoidmise seisukohast. Sama rõhutavad ka teiste kultuuride uurijad, nt tšehhi etnoloog Leoš Šatava peab väga tähtsaks just noorte huvi tõstmist kultuuriga seotud uuendusprotsessis ( ̌̌atava 2001 ja 2006, lk 46-47).

\section{Kokkuvõte}

Käesolevas uurimuses on kirjeldatud rahvatantsu rühmade teket ning rahvatantsu osa eestluse hoidmisel ja säilimisel pagulaseestlaste kogemuste põhjal. Uurimisrühma huvi keskmes olid Teise maailmasõja järgsed aastad Saksamaal. Intervjuudes leidis kinnitust, et pagulaseestlaste rahvatantsurühmade tekke ja tegutsemise üks olulisi tõukejõude oli enesemääratlemine rahvuskultuuri traditsioonide kaudu. Rahvatantsuharrastus aitas liita välis-Eesti kogukonda ja säilitada eestlust ning organiseerida poliitiliselt raskel ajal ühiseid aktsioone tutvustamaks Eesti okupeerimist.

Intervjuude sisuanalüüsil tuli esile kaks teemat, mida võib esitada järgmiste kategooriate kaudu:

1) rahvatantsu iseloomustavad kategooriad: tantsukohad, ajendid, tantsurühmade tegutsemine, rahvatantsurühmade tegevuse hääbumine ja rahvatantsuhuvi praegu; 
2) rahvatantsu funktsiooni iseloomustavad kategooriad: järjepidevuse jätkamine; kogukonna organiseerimine; sotsiaalne suhtlus ja heaolu; eesti keele säilitamine; enesemääratlemine.

Eesti rahva põgenemine Teise maailmasõja ajal oli massiline ja toimus küllaltki lühikese aja jooksul, mistõttu enamik eestlasi asusid tol ajal välismaale elama etteplaneerimata, suuremate kogukondadena ning veendumusega, et võõrsil olek on lühiajaline. Turvatunde tagamiseks püüti kujundada võõrast keskkonda koduseks - eestipäraseks. Tarve rajada oma väike Eesti Saksamaal oli ilmselt suurem kui soov integreeruda saksa ühiskonda, sest eeldati, et varsti pöördutakse koju tagasi. Eesti keel, rahvalaul ja -tants ning rahvarõivad olid olulised kultuuri-ja identiteedikandjad ning toetajad, mis võimaldasid alal hoida rahvuslusega seotud positiivset imagot. Intervjuude põhjal ei olnud rahvatantsijatele olulised niivõrd õiged tantsusammud kuivõrd eesti rahvatantsu tantsimine ja rahvarõivad, mille puhul hinnati ehtsust. Ka rahvatantsu eestvedajatel ja juhtidel ei pruukinud olla väljaõpet - soov tantsida ja õpetada oma lastele rahvatantsu käivitas inimestes sihikindluse tantsud selgeks õppida ja neid teistele edasi õpetada. Enne Teist maailmasõda rahvatantsujuhi ja tantsuloojana tuntuks saanud Ullo Toomi oli Ülemaalise Eesti Noorsoo Ühingu laulu- ja tantsukavade koostaja 1934, 1939, 1940. Tema 1953. aastal ilmunud 575-leheküljeline eesti rahvatantsude kogumik kujunes laialt kasutatavaks õppematerjaliks ka Saksamaa eestlastel. Kultuuriharrastused olid sillaks mineviku ja oleviku vahel, need aitasid tasakaalustada traagilist tõdemust, et ajutisest varjupaiga otsimisest on saanud kestev pagulus, nende toel hoiduti takerdumast pagulase troostitusse imagosse. Teadagi ei vaadanud ju sakslased laagrisolijaile eriti hästi ja kõik püüdsid sealt võimalikult ruttu välja saada. Nii sai võimalikuks luua paguluses oma väike Eesti, end selles eestlastena määratleda (vastus küsimusele, kes me oleme) ning kindlustada järjepidevus (eesti kultuuriga seotud teadmiste ja oskuste edasiandmine noortele).

Intervjuusid läbis rahvatantsu ja eesti keele seoste rõhutamine. Kultuuriharrastused olid võimalus ja vahend säilitada ja õpetada järelpõlvele eesti keelt. Keel, mida inimene kasutab suheldes oma ühiskonnaga, on semiootiline tööriist selle isiku intra-psühholoogilises süsteemis, suunates seda, kuidas inimene mõtleb, tunneb ja vormib oma väljaütlemisi (Valsiner 2007a: 28). Intervjuudes kajastus nii lapsepõlves kogetud rangus eesti keele kõnelemise nõude osas, kui ka uhkus keele oskamise üle. Oma ideede, visioonide, motivatsiooni ja vitaalsusega püüdis vanem põlvkond noortele edasi anda oma suhtumist, lojaalsust ning uhkustunnet olla eestlane. Soov suhelda eesti keeles oli ka eestlaste praeguste kokkutulekute oluline motivaator. 
Andrus Saareste (1956: 31-41) on esitanud kolm rahvuslikku kohustust: poliitilise välisvõitluse organiseerimine Eesti iseseisvuse taastamise heaks, eesti keele ja kultuurilise omapära säilitamine ning demokraatliku Eesti Vabariigi ideaali alalhoidmine. Rahvatants, kuigi esmalt meeldiv harrastustegevus ja ajend kooskäimiseks, oli pagulaseestlastele fenomenaalne relv rahvusliku kohustuse täitmisel, oli eesti keele kõnelemise ja õppimise vahendaja, aitas poliitiliselt raskel ajal kokku hoida ning oma tantsude ja rahvarõivaste kaudu kohalikule rahvale Eestit lähemalt tutvustada.

Avaldame tänu Eesti Ühiskond Saksa Liitvabariigis (EÜSL) esimehele ning kõikidele selle liikmetele igakülgse toetuse ja vastutuleku eest intervjuude andmisel Bocholtis ja Annabergis ning Hamburgis aastatel 2006-2007.

Uurimisrühm tänab ka Tšehhi Eesti Klubi ja eeskätt klubi laekurit kaasaaitamise eest intervjuude kogumismatkaga seotud transpordiprobleemide lahendamisel.

\section{Kommentaarid}

1 Käesolev artikkel seostub ETF grandi nr 7231 "Eesti rahvatantsude algupärane koreograafiline tekst ja esitusviis audiovisuaalsete fikseeringute põhjal" raames tehtava uurimusega (2007-2010, grandihoidja E. Rüütel), et käsitleda rahvatantsu säilimist ja rolli laiemas kontekstis. Uuringu esmatulemused esitati TLÜ Kunstide Instituudi korraldatud rahvusvahelisel teadusseminaril 30. aprillil 2008.

2 Samas peab lisama, et DP Kroonikas võib leida rahvatantsuharrastusest pikema käsitluse ainult lk 825. Väljaspool Eestit asub mitmeid pagulasarhiive, kus leidub materjale harrastustegevusest pagulaslaagrites, millest osa on pärast Eesti taasiseseisvumist toodud Eesti raamatukogudesse ja muuseumitesse nt Raud-Pähn, 2001: 19-24; Kumer-Haukanõmm \& Rosenberg \& Tammaru 2006: 170-190.

3 Tallinnas 1934. aastal toimunud suurel võimlemis- ja spordipeol esines 250 rahvatantsupaari Ernst Idla ja Ullo Toomi juhtimisel. Seda on peetud ka esimeseks üleeestiliseks tantsupeoks, mis on praeguseks saanud meie laulupidude paarissündmuseks.

4 Eesti ajaloos on olnud kunstilise eneseväljenduse üheks kõige võimsamaks sümboliks laulev revolutsioon 1987-88, mil Eesti taasiseseisvumise poliitilisi sündmusi toetas eestlaste ühislaul ning temaatiliste laulude loomine.

5 Ka enamik eestlaste kirjutatud raamatutest keskendub Eesti ajaloole, otsides rahvuse identiteedi allikaid minevikust.

${ }^{6}$ Eestlased asusid umbes 170 põgenikelaagris, ka järgnevates intervjuudes meenutati erinevaid laagreid ja harrastustegevust neis. 
7 Tsitaat EÜSL-i esimees Richo Zieminskilt: On igati tore, et [tunnete] huvi seltsielu ja rahvatantsuharrastuse vastu väliseestlaste kogukondades Saksamaal. [---] Eesti Ühiskond Saksa Liitvabariigis toetab igati algatatud projekti jätkamist (Bocholt ja Annaberg, november 2006).

8 Mitmeid intervjuusid ei saanud teha kas kõrge ea või tervisliku seisundi tõttu. Seetõttu jäid intervjueerimata kunagised Kölni ja Belgia tantsujuhid, muusikud. Mõnda neist mäletatakse praegugi kohalikes eestikeelsetes lehtedes (Eesti Rada, 2004 september, oktoober 4 (787), lk 7).

\section{Kirjandus}

Anniste, Kristi \& Kumer-Haukanõmm, Kaja \& Tammaru, Tiit (toim) 2008. Sõna jõul: diasporaa roll Eesti iseseisvuse taastamisel. 6. ja 7. augustil 2008 Jõhvis toimunud konverentsi kogumik. Tartu: Tartu Ülikooli Kirjastus.

Bellelli, Guglielmo \& Curci, Antonietta \& Leone, Giovanna 2007. Social and cognitive determinants of collective memory for public events. Jaan Valsiner \& Alberto Rosa (toim). The Cambridge handbook of sociocultural psychology. New York: Cambridge University Press, lk 627-644.

Bertricau, A (koostaja pseudonüüm) 2001. Eesti identiteet ja iseseisvus. Tallinn: Avita.

Erelt, Pekka 2004. Sõjapõgenikuna Saksamaal. Eesti Ekspress 19. detsember (https:// paber.ekspress.ee/viewdoc/A382143F0FE613C5C2256F63003DE3D6 - 8. aprill 2009).

Karu, Kristel \& Valk, Aune. 2005. Eestlaste identiteet Eestis ja Rootsis: Erinevate kontekstide ja põlvkondade võrdlus. Akdeemia 9, lk 1972-2009.

Katus, Kalev 1997. Eesti ja eestlus rahvastikuteadlase pilguga. Kuli, H. \& Metsis, K. \& Tammaru, T., (toim). Eestlane olla .... Eesti keele ja kultuuriperspektiivid. Tartu:Tartu Ülikooli Kirjastus, lk 71-93.

Kool, Ferdinand 1999. DP Kroonika: Eesti pagulased Saksamaal 1944-1951. Lakewood, New Jersey: Eesti Arhiiv Ühendriikides.

Korb, Anu 2005. Venemaal rahvuskaaslasi küsitlemas: folkloristliku välitöö metoodilisi aspekte. Tartu: Tartu Ülikooli Kirjastus.

Korb, Anu 2001. Ajalugu ja pärimus: Siberi eestlaste jutud oma esivanematest. Mäetagused 15, lk 48-64.(http://www.folklore.ee/tagused/nr15/korb.htm - 8. aprill 2009)

Kõiva, Mare 2007. Austraaliaeestlased: migratsioon, kohesioon ja ruumimudelid. Kõiva, Mare (koost). Paar sammukest XXIII. Eesti Kirjandusmuuseumi aastaraamat. Tartu: Eesti Kirjandusmuuseumi teaduskirjastus, lk 33-70. (http://www.folklore.ee/rl/pubte/ ee/araamat/2007/2marekoiva.pdf 6. aprill 2009).

Kõiva, Mare 2003. Lugu suurest lumesajust I. Rootsieestlaste isikujutud Nõukogude Eestist. http://haldjas.folklore.ee/tagused/nr.23/lumetorm1.pdf, lk 56-94.

Kumer-Haukanõmm, Kaja \& Rosenberg, Tiit \& Tammaru, Tiit (toim) 2006. Suur põgenemine 1944. Eestlaste lahkumine läände ning selle mõjud. 22. oktoobril 2004 Tartus 
toimunud rahvusvahelise teaduskonverentsi artiklite kogumik. Tartu: Tartu Ülikooli Kirjastus.

Lenovský, Ladislav 2006. Kontexty identity. Ethnologia Actualis Slovaca 6, lk 12-24.

Ojamaa, Triinu \& Rüütel, Ingrid (koost. ja toim.) 2002. Pärimusmuusika muutuvas ühiskonnas I. Töid etnomusikoloogia alalt 1. Tartu: Eesti Kirjandusmuuseumi etnomusikoloogia osakond.

Raudkats, Anna 1926. Eesti rahvatantsud. Tartu: Postimees.

Raud-Pähn, Mai, 2001. Rootsi eestlaste arhiiviküsimused. Rahvuslik Kontakt. Rootsi Eestlaste Liidu väljaanne 1(169), lk 19-24.

Rüütel, Ingrid \& Tiit, Ene-Margit 2005. Pärimuskultuur Eestis - kellele ja milleks I. Tartu: TÜ Kirjastus.

Rüütel, Ingrid \& Tiit, Ene-Margit 2006. Pärimuskultuur Eestis - kellele ja milleks II. Tartu: TÜ Kirjastus.

Rüütel, Ingrid 2002 (koost ja toim). Pärimusmuusika muutuvas ühiskonnas I. Töid etnomusikoloogia alalt 1. Tartu: Eesti kirjandusmuuseumi etnomusikoloogia osakond.

Rüütel, Ingrid 2004 (koost ja toim). Pärimusmuusika muutuvas ühiskonnas II. Töid etnomusikoloogia alalt 2. Tartu: Eesti kirjandusmuuseumi etnomusikoloogia osakond.

Saareste, Andrus 1955. "Kadunud kümmetuhat" ja ka teised. Eesti Üliõpilaste Seltsi album XII. Stockholm: Eesti Üliõpilaste Seltsi vanematekogu kirjastus, lk 31-41.

Šatava, Leoš 2001. Jazyk a identita etnických menšin: možností zachování a revitalizace. Praha: Cargo Publishers o.s, Mikros.

Šatava, Leoš 2006. Regionální jazyky jako emancipační strategie (latgalština a võroseto - dva př́klady z Pobaltí). Ethnologia Actualis Slovaca 6, lk 42-50.

Toomi, Ullo 1953. Eesti rahvatantsud. Tallinn: Eesti Riiklik Kirjastus.

Valk, Aune \& Karu Kristel 2002. Eesti identiteet Eestis ja Rootsis. Valk, Aune (koost). Eesti ja eestlased võrdlevas perspektiivis. Kultuuridevahelisi uurimusi 20. sajandi lõpust. Tartu: Tartu Ülikooli Kirjastus, lk 125-164.

Valsiner, Jaan 2007a. Culture in minds and societies: Foundations of cultural psychology. Thousand Oaks, CA: Sage Publications.

Valsiner, Jaan 2007b. Human Development as migration: Striving towards the unknown. Simão, Livia Mathias \& Valsiner, Jaan (toim). Otherness in question: Labyrinths of the self. Charlotte, North Carolina: Information Age Publishing, lk 349-378.

Weinrich, Peter 1989. Variations in Ethnic Identity: Identity Structure Analysis. Liebkind, Karmela (toim). New Identities in Europe: immigrant ancestry and the ethnic of youth. Aldershot: Gower, Hants, lk 50-73.

Vissel, Anu 2004. Rahvatantsu asendist eestlaste kulturipildis ja harrastustes. Rüütel, Ingrid 2004. Pärimusmuusika muutuvas ühiskonnas II. Töid etnomusikoloogia alalt 2. Tartu: Eesti kirjandusmuuseumi etnomusikoloogia osakond, lk 109-131. 


\title{
Summary
}

\section{Folk Dancing among Estonian Expatriates and Its Role in the Preservation of Estonian Identity}

\author{
Iivi Zajedova, Eha Rüütel, Angela Arraste, Kalev Järvela
}

Key words: expatriate Estonians, folk dance, Germany, hobby activity, identity, qualitative study

The current article is based on the research carried out among expatriate Estonians living in Germany. The aim of the research was to obtain an general understanding of the evolution and development of Estonian folk dance groups and the inception of these groups in the Federal Republic of Germany after the Second World War. The first target group was the Estonian expatriates in Germany, since German war refugee camps were the first stop for many refugees on their journey. Interviews were conducted with 13 expatriate Estonians in Bocholt, Bonn and Hamburg in 2007.

The study attempts to answer the following questions: What gave rise to such active hobby activities, including the establishment of folk dance groups, in German refugee camps? Why were these groups formed also in different places in Germany later, after people had left the refugee camps? What could be the main reasons for and the general context of such a phenomenon?

The article describes the motives for practicing folk dancing as a hobby, the everyday activities of folk dance groups - repertoire, practicing, music, folk costumes and performances, what has become of the folk dance groups since their establishment and the role of folk dance in the life of expatriate Estonians. Aside from the previous aspects, the functions which describe the role of folk dance - preservation of continuity; organisation of community; social interaction and welfare; preservation of Estonian language; self-determination - also stood out in the analysis of the interviews.

Cultural pursuits formed a positive link between the past and the present, taking on a balancing role in the tragic understanding that seeking temporary asylum had become a constant state in exile and this prevented people from being trapped in the disconsolate condition of a refugee. Folk dance was not purely a hobby but a place where the Estonian language was spoken and learned; it helped people to stick together in difficult times, define themselves in the wind of changes and introduce Estonia in a foreign country by means of dance and folk costumes. 